\title{
A Study of Subject-Verb Agreement: From Novice Writers
}

\author{
to Expert Writers
}

\author{
Surina Nayan \\ Academy of Language Studies, Universiti Teknologi MARA Perlis \\ 02600, Arau Perlis, Malaysia \\ Tel: 60-19-562-5843Ｅ-mail: surinana@perlis.uitm.edu.my \\ Kamaruzaman Jusoff (Corresponding author) \\ Faculty of Forestry, Universiti Putra Malaysia, Serdang 43400, Selangor. Malaysia \\ Tel: 60-3-8946-7176 E-mail: kjusoff@yahoo.com
}

\begin{abstract}
Students in higher learning institutions need to write lots of reports based on the projects done. Since they are at the tertiary level of education, they are required to use English in their reports. This is to ensure that they are able to function well in English later at the workplace. Writing requires students to apply rules regarding sentence structures, grammar and also its mechanic that refers to punctuation and capitalization. However, many of the students have problems in applying these rules in their writing even though they have been learning English for about 12 years in school. This is a case study on BEL 311, semester 3 students at one local higher learning institution that comprises 'Bumiputra' (a Malay term widely used in Malaysia, embracing ethnic Malays, Javanese, Bugis, Minang and other indigenous ethnic groups such as the Orang Asli in Peninsular Malaysia and the tribal peoples in $\underline{\text { Sabah }}$ and $\underline{\text { Sarawak) }}$ students regarding their problems with subject-verb agreement in their writing. These students are required to write a term paper that worths $30 \%$ out of their $100 \%$ total score. They are taking their BEL 311, English for Academic Purposes -an undergraduate diploma course. The researcher gathered information for this study through her observation, interview and written assignment given to students. The findings from the study are of significant important since this will help the lecturers to further enhance their teaching methods and find ways to help students improve their writing and avoid making errors in subject-verb agreement as possible.
\end{abstract}

Keywords: L1, L2, Bumiputra, Errors, Mistakes, Bahasa Malaysia, Universiti Teknologi Mara (UiTM), ESL

\section{Introduction}

"I always have lots of errors in my writing. I am not confident with my English."

"I don’t know why I still have problems with my grammar even though I have learnt all the rules before."

"It is quite confusing when you have a singular subject in a sentence, but you have to add 's' to the verb. I don't have this kind of rule in Bahasa Malaysia (the Malay Language spoken in Malaysia)."

These are some of the statements and complaints received from my students. Majority of these students still have problems with their subject-verb agreement in their writing. In English Language, the subject must agree with the verb. If the subject is singular, a singular verb is required. On the other hand, a plural subject takes a plural verb. This rule applies greatly in Simple Present Tense. Therefore, any mistakes made by the students in agreement are very noticeable. In Simple Past Tense, however, only the verbs 'was' and 'were' need to be considered. This is the general rule for subject-verb agreement. Besides, having its general rules, it also has its sub-rules. Based on my observation, I noticed that my students have mistakes in these both general and sub-rules of subject-verb agreement in their writing. The researcher tried to investigate the difficulties in the use of subject-verb agreement in their writing and also to determine remedial actions that need to be taken in order to overcome their difficulties in using subject-verb agreement correctly in their written performance.

\section{Literature review}

Students need to clearly write what they want to convey in order to transmit their messages effectively to the receiver. In other words, choices of words and correct grammatical rules need to be employed by them. However, these students of L2(a language which is not a native language in a country but, it is widely used as a medium of communication) in the researcher's class have difficulties in constructing correct sentences in English. This is because they have problems in the subject-verb agreement rules. These students have problems in subject-verb agreement because in their L1 (generally a person's mother tongue or the language acquired first) which is Bahasa Malaysia, it 
doesn't have rules regarding subject-verb agreement. That's why majority of learners have problems in their writing. All subjects either singular or plural require the same form of verb. For example:

$\begin{array}{lll}\text { Abu pergi } & \text { ke kedai. } \\ \text { (subject) } & \text { ( verb) } & \text { (expansion) }\end{array}$

Abu dan Amin pergi ke kedai.
Abu-singular subject

Abu and Amin-plural subjects

This is supported by Bahiyah \& Basil Wijayasuria (1998) where they find that Malay learners have difficulty in the subject-verb agreement because Bahasa Malaysia does not differentiate between person and, therefore it is not necessary for verbs to agree with the subject. In English, however, this is essential in the present tense and with the verb 'be'. Because of this, it creates confusion among learners. These students tend to make errors in their writing. Although the subject-verb agreement structure was introduced early to students i.e. when they were in the primary level, they still face problem in acquiring the correct form of it. Murcia \& Freeman (1983) as cited by Nor Arfah (1988), state that in spite of the early introduction and the superficially simple rules of the subject-verb agreement, they still pose problems for the ESL learners at all levels or proficiency. Some examples from an advanced level Malay ESL learner are as follows:

It really make me unhappy. Fortunately, my family especially my father need me to help his business. Recently, my father want to expand his business by selling LPG gas. It really tedious to get a license.

As the example shows, the learner failed to employ the correct rule of subject-verb agreement where a singular subject requires a singular verb. The learner's writing should be:

It really makes me unhappy. Fortunately, my family especially my father needs me to help manage his business. Recently, my father wants to expand his business by selling LPG gas. It is really tedious to get a license.

Hughes \& Heah (1989) state that some examples of the typical mistakes made by the Malaysian speakers of English are:

I cannot work anymore. My body feel weak. (My body feels)

Foreigners are people who comes from another country. (people who come)

Everybody were watching to see what would happen next. (Everybody was)

In addition, Munir (1991) in his research on the various types of agreement in English, finds out that the subject-verb agreement (especially the number agreement) appears to be the most problematic area faced by Malaysian learners of English. Some examples are:

Their students is in good health.

Boarding schools is better than day schools.

As the examples show, the learner again failed to employ the correct rule of subject-verb agreement.

Writing involves constructing sentences correctly. Therefore, in English for students to effectively communicate their ideas well in writing, they must be able to construct meaningful sentences that have correct grammar. Dorn (2000) states that the sentences created by words and phrases are the essential blocks of meaning that allow us to communicate thoughts. If there are not constructed carefully, they can make reading difficult. He further states that major basic usage and grammar slips in written English are those associated with verbs. Based on the fact that subject-verb agreement area is very important to express ideas especially in writing, where non verbal communication is absent, the students really need to master this rule in order to write effectively. As a result, they can convey their message clearly and effectively. By writing a piece of work that is error free, it shows that learners have mastered the English grammar rules and it will give a good impression to others who read their work.

\section{Method}

The study dealt with the subject-verb agreement in students' written production. The written method is used because of several reasons. The first reason is that written work can test the students' comprehension and production of the grammatical rules they have already learnt in a more appropriate way. Besides, when they are given a chance to choose their own topic for their term paper, they can have more freedom to write on the topic that interests them. In order to gather the information needed for the study, the researcher has referred to her students' term papers. These students are semester three students from Diploma in Industrial Chemistry. They have to take BEL 311 (English for Academic Purposes) this semester that is semester December 2008-April 2009. They have to write a term paper that worths $30 \%$ from the total overall score of $100 \%$. Previously, they had taken two English papers in semester one and semester two. The samples involved in this study are the L2 learners of English since they use Bahasa Malaysia as their L1. These students who are taking BEL 311 have to write a term paper that requires them to be critical and creative in their 
thinking where they have to search for one issue that interests them and write on it. At the same time, they have to find causes for the problem and offer solutions to it. This term paper should be done in pairs. They are advised to use 450-700 words for their term paper. They should also include in- text citations in their term paper. This requires them to do library research for information. Some of them also conduct their own interview to get the information needed. In order to get information needed for the study, the researcher who is the lecturer at UiTM (a university that offers quality programs to Bumiputras) interviewed some students randomly in her class regarding their problems in using the subject-verb agreement in their writing. The researcher also observed these students when they do their written work in class especially when they discussed and brainstormed their ideas. The researcher had 6 contact hours per week with her students. The researcher spent 14 weeks with these students this semester. Within these 6 hours, the researcher had to focus on the other components under BEL 311 syllabus which are Reading Comprehension, Speaking and Grammar. Students' written work was checked several times before they submitted the final draft. Students were required to submit their first draft of their term paper including the in-text citation before they submitted their final draft. This first draft was marked and checked by the researcher. Then, this draft was returned back to the students for their final revision and final submission. These students were not aware that their work would be used in this study. The reason why they were not told is because the researcher wanted to let the students freely write their sentences without having any conscious feeling that their writing is going to be analyzed. The sample errors in this research are taken from their first draft work.

\section{Results and discussion}

As in the researcher's class, these students have studied English for almost 12 years. Unfortunately, they still make subject-verb agreement errors in their writing. According to Corder (1967), an error refers to a systematic deviation made by learners who have not yet mastered the rules of L2. A learner cannot self-correct an error because it is a product reflective of his or her current stage of L2 development or underlying competence. A mistake, on the other hand refers to a random performance slip caused by fatigue, excitement etc and can be readily self corrected. Therefore, as their lecturer I would like to help them minimize if not stop them from making this error in subject-verb agreement. My students have taken 2 English papers so far in their diploma course, this BEL 311 is their third paper. From my observation and my experience teaching them this semester (December 2008-April 2009) for almost 12 weeks, I can conclude that my students are having difficulty in correctly and effectively use the subject-verb agreement rules in their writing. Furthermore, they can be put under the category of novice writers. Scardamalia \& Bereitner (1986) as cited in Lee (2004) state that novice writers use the trial-and-error approach to trigger more writing. They also spend little time planning and start off writing although they are still confused about the task (Richard, 1990 as cited in Lee 2004). This is evidence in my students writing where they tend to just quickly write their term paper without proper planning since they say that they are struggling with other subjects as well.

According to Hyland (2006), novice writers are not used to seeing writing as interactive or to imagining the perceptions, interests and requirements of a potential audience. Thus, it is a duty of the lecturer to create greater reader awareness among their students. Students should be told that they are writing for other readers as well not just for themselves.

On the other hand, skilled writers or expert writers are those who are able to handle audience concerns and consider more perspectives with regard to their rhetorical problem. They also develop more sophisticated thinking about the writing topic through inferences about their audience and their anticipated response and evaluation of their arguments and assumptions against their reader's imagined position. Conversely, the less skilled writers are writers who have limited linguistic ability in English and difficulty in problem-finding and problem-solving (Hanizah \& Moore, 2003)

From the first draft submitted by the students, I noticed that they have difficulties in general and sub -rules of subject verb agreement. The following are sample errors made by these students.

1) Nobody care for health and fitness till the age of 30 or 35 years, but after crossing the 40 's, we find a lot of changes in our activity and work style.

2) Psychologist believe that pressure is the cause for hysteria attacks (Nizam, 2005).

3) These are the symptoms shown when someone were attacked by hysteria.

4) As we look around at the atmosphere of university, we tend to find many couples and some of these couple end up getting married while studying.

5) So, it show that every person in this world include the students have their own spouse to get married and it is not wrong for them to get married early.

6) Spouse who choose to get married early tend to face with a lot of problems because they do not have their own money to support their lives.

7) The number of unmarried women who is having a good career has increased. 
8) For example, Anis Ramlee, the mother of three and the group CEO of Esthetics International believe the childhood experiences given her the firmness, guts and strength to pursue whatever passions she has.

9) The man need to have a good family background.

10) One of the benefits when student involve in sports is they can manage their stress.

11) Student who come from either a primary school, secondary school, college, university or even 'pondok' (religious school) have their own learning styles.

12) Good and smart style promise better results, but bad style can fail them.

13) Difficulty in controlling teenagers' desire to stay on-line for long period is one of the factors that make them addicted to the internet.

14) All the problem have its solution.

15) It is very clear that smoking cause this problem.

Based on the above findings, it can be concluded that students have more tendency to make errors in the general rule of subject verb agreement. This may be because they try to avoid using the sub rule of subject verb agreement. This is proven since majority of the errors made are under the general rule of subject verb agreement.

Another factor that causes them to make errors in subject verb agreement is because of the L1 interference (inter language errors) where these students notice that in their L1, there is no rule which says that a singular subject requires a single form of verb. Besides, faulty generalization or over-generalization also involves where a deviant structure has been constructed by these students based on their experience of other structures in the target language. It can also be concluded that interference from the native language is a source of difficulty in second language learning.

Since the subject and the verb are two most important components in constructing correct and complete sentences in English, students should be made aware their importance. Thus, it is important for the lecturers in general who are teaching BEL 331 to do revision on grammar especially on subject verb agreement at the beginning of the semester before they start writing their term paper. Exercises in subject verb agreement should also be given to them to ensure that they master in subject verb agreement. Exercises on error correction especially on subject verb agreement should be done more to make them familiar with the correct rules of subject verb agreement. In writing their term paper, these students actually avoided using the sub-rules of subject verb agreement. The avoidance strategy used by them should not be encouraged especially in their writing. These students should be made aware that all subject verb agreement rules are important in their writing, so there will be variations in terms of words and styles used to explain something. As a result of this, their piece of writing will be more interesting and enjoyable for the reader to read.

Lecturers should also consider using direct approach in teaching grammar at the beginning of semester 3 before these students start writing their term paper. Direct approach involves teaching the rules first then the students need to apply these rules in their writing. In addition, students who have more problems in the usage of subject verb agreement should be grouped together and more attention should be given to teaching them. Another possible way to employ in reducing errors made by them in subject verb agreement is to get students to check each other's work. This will involve them in an active search for errors and English can be used for a genuine communication while discussing these errors in class. By adopting and implementing the above suggestions, hopefully the students will do well in their term paper and can further enhance their writing skills.

\section{Conclusion}

There is evidence that students still possess problems in the usage of their subject verb agreement in their writing. Majority of the students have problems in their general rule than sub-rules. Students have problems in subject-verb agreement because they don't have this kind of rule in their L1. Furthermore, since these students have to concentrate their study on other subjects learnt this semester, they don't really put as much effort as they could to further improve their writing. Besides, some student didn't realize that they made errors in their writing since they have problems in this area. Therefore, remedial actions should be taken in order to help them produce a good piece of written work. Lecturers can employ direct approach in teaching these students and at the same time organize activities which are related to subject verb agreement. These students should also be allowed to do peer- correction to their term paper and other activities on subject verb agreement together to involve them in learning directly. By doing this, hopefully the students can improve their writing and can function well in English.

\section{References}

Bahiyah Abdul Hamid \& Basil Wijayasuria. (1998). English Grammar for Malaysians. Bangi: Universiti Kebangsaan Malaysia.

Corder, S.P. (1967). The significance of learners' errors. IRAL Vol. 5, No. 4. Pp.161-169. 
Dorn, D. (2000). Building Essays: A reader centered writing guide. New Jersey: Prentice Hall.

Hanizah Zainuddin \& Moore, R. A. (2003). Audience awareness in L1 and L2 composing of bilingual writers. [Online] Available: http://www.cc.kyoto-su.ac.jp/information/tesl-ej/ej25/a2.html (February 03, 2009).

Hughes, R. \& Heah, C. (1990). Common errors in English (Grammar Exercises for Malaysians). Kuala Lumpur: Sun U Book Co. Sdn. Bhd.

Hyland, K. (2006). Representing readers in writing: Student and expert practices. [Online] Available:http://www.sciencedirect.com/science?_ob=ArticleURL\&_udi=B6W5S-4K7FJGN-(February 10, 2009).

Lee, C. C. (2004). Seeing is understanding: Improving coherence in students' writing. [Online]Available:http://iteslj.org/Techniques/Lee-Writing (February 10, 2009).

Munir Shuib (1991). An analysis of Malaysian learners' English agreement errors. University of Essex.

Nor Arfah Haji Ahmad. (1988). The performance of Malay High School Students on Subject-verb agreement measured by Four Testing Methods. M.A. Dissertation. Colorado State University. 